\title{
Absence of HER2 Expression of Circulating Tumor Cells in Patients with Non-Metastatic Esophageal Cancer
}

\author{
ANNA WOESTEMEIER ${ }^{1 *}$, TARIK GHADBAN ${ }^{1 *}$, SABINE RIETHDORF $^{2}$, \\ KATHARINA HARMS-EFFENBERGER ${ }^{2}$, LEONIE KONCZALLA ${ }^{1}$, FAIK G. UZUNOGLU ${ }^{1}$, \\ JAKOB R. IZBICKI ${ }^{1}$, KLAUS PANTEL ${ }^{2}$, MAXIMILIAN BOCKHORN ${ }^{1}$ and MATTHIAS REEH ${ }^{1}$ \\ ${ }^{1}$ Department of General, Visceral and Thoracic Surgery, \\ University Medical Centre, Hamburg-Eppendorf, Hamburg, Germany; \\ ${ }^{2}$ Department of Tumor Biology, University Medical Centre, Hamburg-Eppendorf, Hamburg, Germany
}

\begin{abstract}
Background/Aim: The clinical significance of circulating tumor cells $($ CTC) in non-metastatic esophageal cancer (EC) remains controversial and the cellular and molecular characteristics of CTCs are poorly understood. Especially the frequency and oncological impact of HER2 expression in CTCs in patients with EC have not been evaluated until now. Materials and Methods: In this singlecenter, prospective study, peripheral blood samples were obtained preoperatively from 45 patients who were diagnosed with resectable EC. CTC detection and HER2 expression were performed using the CellSearch System. Data were correlated with clinicopathological parameters and patient outcomes. Results: The study included 13 patients with squamous cell carcinomas (SCC) and 32 patients with adenocarcinomas (AC). HER2 gene amplification in the primary tumor was detected in $9.1 \%$ of patients. One or more CTCs were detected in 15.6\% (SCC 1/13; AC 6/32) of the patients. None of the detected CTCs showed HER2 expression. Patients with CTCs showed significantly shorter relapse-free $(p<0.001)$ and overall survival ( $p=0.015$ ) than CTC-negative patients. Conclusion. This is the first study analyzing HER2 expression and the clinical significance of CTCs in patients with non-metastatic EC using an automated immunomagnetic detection system. HER2 expression in CTCs is very rare in patients with nonmetastatic EC and seems to have a low clinical and oncological impact.
\end{abstract}

\footnotetext{
*These Authors contributed equally to this study.

Correspondence to: Matthias Reeh, MD, General, Visceral and Thoracic Surgery, University Medical Centre of HamburgEppendorf, Martinistraße 52, 20246 Hamburg, Germany. Tel: +49 40741052401, e-mail:mreeh@uke.de
}

Key Words: Esophageal cancer, circulating tumor cells, HER2.
Cancer of the esophagus, despite technical advances, is still a highly lethal malignancy. Most esophageal cancers (EC) are squamous cell or adenocarcinomas. Although the incidence of squamous cell carcinoma (SCC) is decreasing, the incidence of adenocarcinoma (AC) arising from Barrett's esophagus is dramatically increasing.

More than two thirds of all patients with esophageal cancer develop metastases or local recurrence and circulating tumor cells (CTCs) or disseminated tumor cells are supposedly playing a key part in this development (1-3). Previous studies showed that the presence of CTCs is correlated with shorter overall survival in patients with metastatic disease $(1,4,5)$. In EC, CTC detection is an independent prognostic marker of overall and recurrence-free survival. However, its significance in non-metastatic EC remains controversial and the molecular biological characteristics of CTCs are poorly understood $(4,6)$.

The human epidermal growth factor receptor gene HER2 is known to play a role in the development of malignancies and is often linked to a poor prognosis, for example in breast cancer (7). The HER2-inhibitor trastuzumab has been shown to be very effective against breast cancer overexpression HER2 (8, 9). In EC however, there is no correlation between the presence of HER2 in the primary tumor and patient survival (10-12). Stoecklein et al. showed that HER2 gain in at least a single disseminated tumor cell (DTC) in bone marrow was a prognostic factor of poor survival (13). However, the frequency and oncological impact of HER2 expression in CTCs in patients with EC has not been evaluated until now.

\section{Materials and Methods}

Patients. Forty-seven patients with non-metastatic EC were prospectively enrolled in this single-centre study. All patients underwent surgery at the University Hospital Hamburg-Eppendorf, and in all cases no evidence of metastatic disease was evident in preoperative staging. Forty-five patients had an en-bloc esophageal resection with radical lymph node dissection with curative intention. 
Table I. Patients' and tumor characteristics.

\begin{tabular}{|c|c|c|c|c|c|c|}
\hline & Patients $(n=45)$ & $\%$ & CTC pos. & $\%$ & $p$-Value & HER 2 pos. CTC \\
\hline All & 45 & 100 & 7 & 15.6 & & \\
\hline Gender & & & & & 0.583 & \\
\hline Male & 35 & 77.8 & 6 & 17.1 & & 0 \\
\hline Female & 10 & 22.2 & 1 & 10 & & 0 \\
\hline 0 & & & & & & \\
\hline Age (years) & & & & & 0.826 & \\
\hline$\leq 65$ & 24 & 55.3 & 4 & 16.7 & & 0 \\
\hline$>65$ & 21 & 44.7 & 3 & 14.3 & & 0 \\
\hline pT stage & & & & & 0.152 & \\
\hline $\mathrm{T} 1$ & 12 & 26.7 & 2 & 16.7 & & 0 \\
\hline $\mathrm{T} 2$ & 9 & 20.0 & 0 & 0 & & 0 \\
\hline $\mathrm{T} 3$ & 20 & 44.4 & 3 & 15.0 & & 0 \\
\hline $\mathrm{T} 4$ & 4 & 8.9 & 2 & 50.0 & & 0 \\
\hline pN stage & & & & & 0.999 & \\
\hline NO & 25 & 55.6 & 4 & 16.0 & & 0 \\
\hline N1 & 7 & 15.6 & 1 & 14.3 & & 0 \\
\hline N2 & 6 & 13.3 & 1 & 16.7 & & 0 \\
\hline N3 & 7 & 15.6 & 1 & 14.3 & & 0 \\
\hline Stage groups (UICC) & & & & & 0.581 & \\
\hline IA & 11 & 24.4 & 2 & 18.2 & & 0 \\
\hline IB & 4 & 8.9 & 0 & 0 & & 0 \\
\hline IIA & 9 & 20.0 & 2 & 22.2 & & 0 \\
\hline IIB & 4 & 8.9 & 0 & 0 & & 0 \\
\hline IIIA & 3 & 6.7 & 0 & 0 & & 0 \\
\hline IIIB & 4 & 8.9 & 0 & 0 & & 0 \\
\hline IIIC & 10 & 22.2 & 3 & 30.0 & & 0 \\
\hline Histology & & & & & 0.354 & \\
\hline $\mathrm{SCC}$ & 13 & 28.9 & 1 & 7.7 & & 0 \\
\hline $\mathrm{AC}$ & 32 & 71.1 & 6 & 18.8 & & 0 \\
\hline Barrett's esophagus & & & & & 0.100 & \\
\hline No & 36 & 80.0 & 4 & 11.1 & & 0 \\
\hline Yes & 9 & 20.0 & 3 & 33.3 & & 0 \\
\hline HER2 status of primary tumor & & & & 0.051 & & \\
\hline Negative & 40 & 90.9 & 5 & 12.5 & & 0 \\
\hline Positive & 4 & 9.1 & 2 & 50.0 & & 0 \\
\hline
\end{tabular}

In two patients, esophagectomy was not performed due to the presence of distant tumor spread detected intraoperatively. These two patients were excluded from the study. Histopathological analysis was performed in accordance with the seventh edition of the tumour-node-metastasis classification (TNM) of the International Union against Cancer (14).

The study was approved by the Ethics Committee of the Hamburg Chamber of Physicians and informed consent was obtained from all patients. Postoperative follow up was conducted at 3-month intervals for the first 2 years and afterwards at 6-month intervals.

Clinical samples. Preoperatively, peripheral blood samples $(7.5 \mathrm{ml})$ were collected in CellSave (Menarini Silicon Biosystems, Castel Maggiore, Italy, former Janssen Diagnostics, Raritan, NJ, USA) preservative tubes, stored at room temperature and processed within $48 \mathrm{~h}$.

CTC enumeration and HER2 determination. CTC enumeration by the CellSearch system (Menarini) was performed using the CellSearch Epithelial Cell Kit (Menarini). The blood samples were enriched for cells that expressed epithelial cell adhesion molecules (EpCAM) with antibody-coated magnetic beads. The nucleus was labelled with fluorescent nucleic acid dye 4,2-diamidino-2phenylidole (DAPI). To distinguish epithelial cells from leukocytes, fluorescently labelled monoclonal antibodies specific for leukocytes (CD45) and epithelial cells (keratins [KER] 8, 18, and 19) were used. The samples were measured by CellTracks Analyzer II (Menarini) and an event was classified as a tumor cell with the phenotype KER+, DAPI+, CD45- and a round or oval cell morphology. The cut-off value for CTC positivity was $1 / 7.5 \mathrm{ml}$.

In order to analyze HER2 expression in the detected CTCs, the CellSearch Tumor Phenotyping Reagent HER-2 (Menarini) was used following manufacturers' instructions. Immunoscoring of HER2 expression by fluorescence intensity was conducted as described by Riethdorf et al. (15).

Statistical analysis. SPSS 22 software (SPSS Inc., Chicago, IL, USA) was used. Histological characteristics were expressed as descriptive statistics. The $\chi^{2}$ test was used to investigate the 

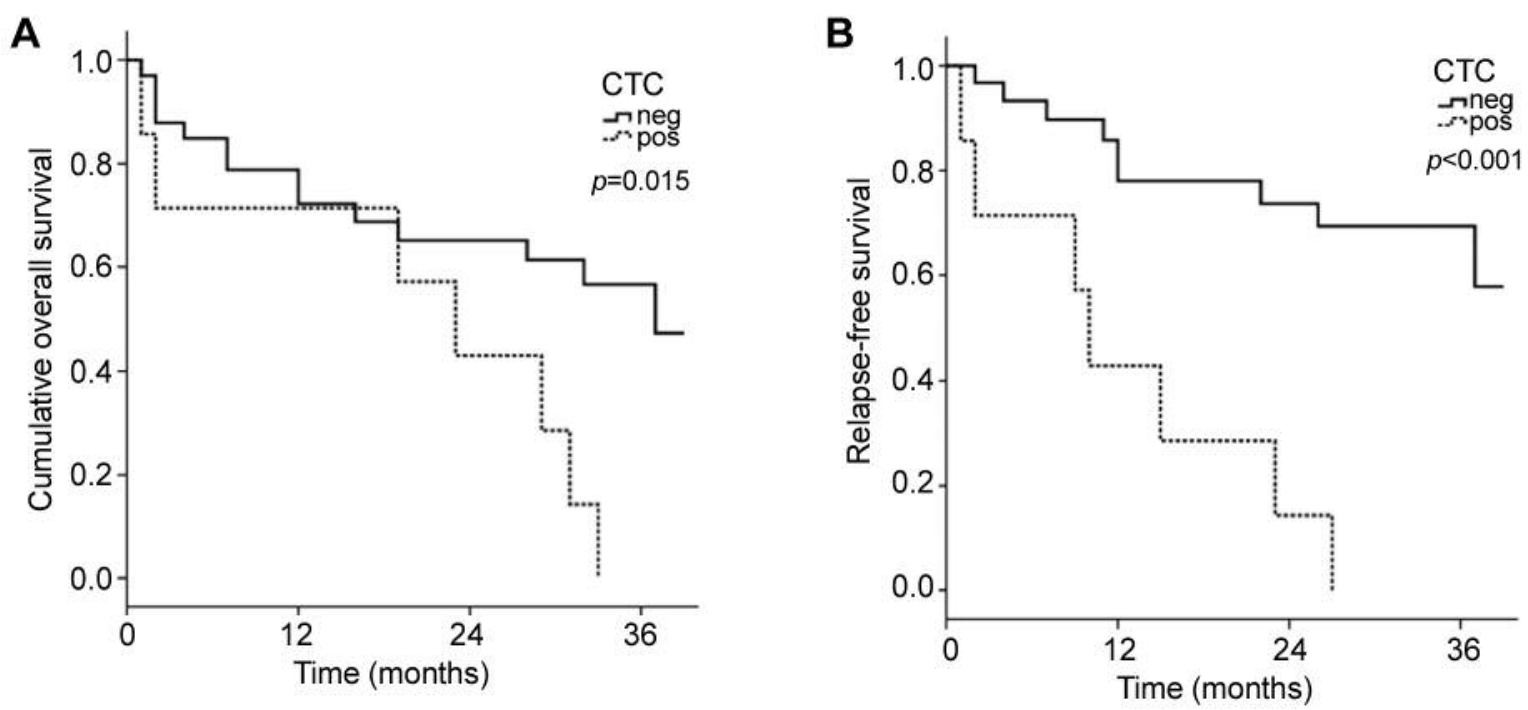

Figure 1. Kaplan-Meier curves for overall (A) and relapse-free (B) survival according to CTC status.

association between CTCs and histopathological parameters. Univariate survival analysis was plotted by the Kaplan-Meier method and analyzed using the log-rank test. The results were presented as the median survival in months with the 95\% confidence interval (CI) and number of patients at risk. Significance was indicated by $p$-values of less than 0.05 in 2-tailed tests.

\section{Results}

Patient characteristics. Overall, 13 patients with nonmetastatic SCC and 32 patients with non-metastatic AC of the esophagus were enrolled. Patient and tumor characteristics are shown in Table I. The mean patient age was 63.3 years, $35(77.8 \%)$ were males and $10(22.2 \%)$ were females (Table I).

CTC detection and HER2 expression. CTCs were detected in $15.6 \%$ of all patients. Of note, CTCs were detected in only 1 of 13 patients with SCC; in this sample 3 CTCs were identified. However, 6 out of 32 patients with AC had 1 CTC or more; in one patient $31 \mathrm{CTCs}$ were detected and in the other five patients 1 CTC was detected. None of the detected CTCs expressed HER2. HER2 gene amplification in the primary tumor was seen in $9.1 \%$ of patients, two of whom were CTC positive and HER2-negative (Table I).

Survival analysis. The median survival time was 37 months. The median follow-up time of the surviving patients was 33 months. Patients with CTCs showed significantly shorter relapse-free $(p<0.001)$ and overall survival $(p=0.015)$ compared to CTC-negative patients (Figure 1). Patients with
HER2-positive primary tumors had no significant difference in overall survival compared to patients with HER2-negative primary tumors $(p=0.846)$.

\section{Discussion}

Preoperative staging in EC remains inaccurate, despite several diagnostic tools, such as endoscopic ultrasound and computed tomography $(16,17)$. Several studies indicated that CTCs play an important role in the metastatic cascade (18-20) and the detection of CTC in peripheral blood was shown to be a useful prognostic indicator of tumor progression and prognostic outcome (1). Thus, analysis of CTCs is a valuable addition to preoperative staging in EC and may give an insight into intratumoral and inter-metastatic heterogeneity (21). Recently, Iwatsuki et al. showed that in patients with metastatic EC the HER2 oncogene is amplified in $32.3 \%$ of patients and its expression is augmented in disseminated and circulating tumor cells (22). The HER2 oncogene encodes for a transmembrane glycoprotein receptor with intracellular tyrosine kinase activity and belongs to the epidermal growth factor receptor family, controlling epithelial cell growth and differentiation $(23,24)$. In metastatic breast cancer, HER 2 is differentially expressed in the primary tumor compared to metastatic foci in 5\% up to $48 \%$ of cases $(15,25)$. This discordance might be useful as a prognostic marker for the clinical outcome of patients with metastatic versus non-metastatic disease. It is also posing a problem in therapeutically targeting HER2 (26). As this treatment will specifically target cells expressing HER2 and not the tumor cells that do not, such a treatment could be 
ineffective $(25,27)$. HER2 expression in metastatic gastrointestinal cancer has been shown to range between 11$73 \%$ of the cases $(10,22)$. In addition, HER 2 has been suggested as a prognostic marker for metastatic esophageal cancer disease $(13,22)$. However, there are no studies on patients with non-metastatic EC.

This is the first study evaluating HER2 expression of CTCs in non-metastatic EC patients by the CellSearch system. This system is the gold standard for selecting and identifying circulating epithelial cells in small amounts $(7.5 \mathrm{ml})$ of blood samples with single-cell sensitivity $(28,29)$. We observed, that the overall and relapse-free survival of patients with detectable CTCs was significantly lower than the survival of CTCnegative patients. In agreement with previous studies, HER2 amplification in the primary tumor did not have a prognostic impact $(13,30)$. In a cohort of 7 CTC positive patients including two with HER2-positive primary tumors, no HER2positive CTCs were detected. This might be due to the fact, that esophageal cancer cells share many chromosomal changes and are well known to have histological heterogeneity. Furthermore, the cut-off value for HER2 positivity in the primary tumor was $10 \%$ and therefore HER2 negative cells may have been present, as well $(13,22,31)$.

\section{Conclusion}

This is the first study analyzing HER2 expression and the clinical significance of CTCs in patients with non-metastatic EC by an automated immunomagnetic detection system. In conclusion, HER2 expression in CTCs is very rare in patients with non-metastatic EC and has no prognostic value, clinical and oncological impact.

\section{Conflicts of Interest}

The Authors declare no conflicts of interest.

\section{Acknowledgements}

This work was supported by the ERC-2010-AdG_20100317 Grant DISSECT to KP.

\section{References}

1 Uenosono Y, Arigami T, Kozono T, Yanagita S, Hagihara T, Haraguchi N, Matsushita D, Hirata M, Arima H, Funasako Y, Kijima Y, Nakajo A, Okumura H, Ishigami S, Hokita S, Ueno S and Natsugoe $S$ : Clinical significance of circulating tumor cells in peripheral blood from patients with gastric cancer. Cancer 119: 3984-3991, 2013.

2 Izbicki JR, Hosch SB, Pichlmeier U, Rehders A, Busch C, Niendorf A, Passlick B, Broelsch CE and Pantel K: Prognostic value of immunohistochemically identifiable tumor cells in lymph nodes of patients with completely resected esophageal cancer. N Engl J Med 337: 1188-1194, 1997.
3 Alix-Panabieres $\mathrm{C}$ and Pantel K: Challenges in circulating tumour cell research. Nat Rev Cancer 14: 623-631, 2014.

4 Reeh M, Effenberger KE, Koenig AM, Riethdorf S, Eichstadt D, Vettorazzi E, Uzunoglu FG, Vashist YK, Izbicki JR, Pantel K and Bockhorn M: Circulating Tumor Cells as a Biomarker for Preoperative Prognostic Staging in Patients With Esophageal Cancer. Ann Surg 261: 1124-1130, 2015.

5 Stephenson D, Nahm C, Chua T, Gill A, Mittal A, de Reuver P and Samra J: Circulating and disseminated tumor cells in pancreatic cancer and their role in patient prognosis: a systematic review and meta-analysis. Oncotarget 8: 107223-107236, 2017.

6 Takeuchi $\mathrm{H}$ and Kitagawa Y: Circulating tumor cells in gastrointestinal cancer. J Hepatobiliary Pancreat Sci 17: 577-582, 2010.

7 Ramos-Medina R, Moreno F, Lopez-Tarruella S, Del MonteMillan M, Marquez-Rodas I, Duran E, Jerez Y, Garcia-Saenz JA, Ocana I, Andres S, Massarrah T, Gonzalez-Rivera M and Martin M: Review: circulating tumor cells in the practice of breast cancer oncology. Clin Transl Oncol 18: 749-759, 2016.

8 Simon R, Nocito A, Hubscher T, Bucher C, Torhorst J, Schraml P, Bubendorf L, Mihatsch MM, Moch H, Wilber K, Schotzau A, Kononen J and Sauter G: Patterns of her-2/neu amplification and overexpression in primary and metastatic breast cancer. J Natl Cancer Inst 93: 1141-1146, 2001.

9 Marx AH, Tharun L, Muth J, Dancau AM, Simon R, Yekebas E, Kaifi JT, Mirlacher M, Brummendorf TH, Bokemeyer C, Izbicki JR and Sauter G: HER-2 amplification is highly homogenous in gastric cancer. Hum Pathol 40: 769-777, 2009.

10 Thompson SK, Sullivan TR, Davies R and Ruszkiewicz AR: Her-2/neu gene amplification in esophageal adenocarcinoma and its influence on survival. Ann Surg Oncol 18: 2010-2017, 2011.

11 Sato-Kuwabara Y, Neves JI, Fregnani JH, Sallum RA and Soares FA: Evaluation of gene amplification and protein expression of HER-2/neu in esophageal squamous cell carcinoma using Fluorescence in situ Hybridization (FISH) and immunohistochemistry. BMC Cancer 9: 6, 2009.

12 Schoppmann SF, Jesch B, Zacherl J, Wrba F, Hejna M, Maresch J, Langer FB, Riegler MF, Pluschnig U and Birner P: HER-2 status in primary oesophageal cancer, lymph nodes and distant metastases. Br J Surg 98: 1408-1413, 2011.

13 Stoecklein NH, Hosch SB, Bezler M, Stern F, Hartmann CH, Vay C, Siegmund A, Scheunemann P, Schurr P, Knoefel WT, Verde PE, Reichelt U, Erbersdobler A, Grau R, Ullrich A, Izbicki JR and Klein CA: Direct genetic analysis of single disseminated cancer cells for prediction of outcome and therapy selection in esophageal cancer. Cancer Cell 13: 441-453, 2008.

14 Sobin LH, Gospodarowicz MK and Wittekind C: TNM classification of malignant tumours. Oxford: Wiley-Blackwell, 2010.

15 Riethdorf S, Muller V, Zhang L, Rau T, Loibl S, Komor M, Roller M, Huober J, Fehm T, Schrader I, Hilfrich J, Holms F, Tesch H, Eidtmann H, Untch M, von Minckwitz G and Pantel $\mathrm{K}$ : Detection and HER2 expression of circulating tumor cells: prospective monitoring in breast cancer patients treated in the neoadjuvant GeparQuattro trial. Clin Cancer Res 16: 2634-2645, 2010.

16 Kutup A, Vashist YK, Groth S, Vettorazzi E, Yekebas EF, Soehendra N and Izbicki JR: Endoscopic ultrasound staging in gastric cancer: Does it help management decisions in the era of neoadjuvant treatment? Endoscopy 44: 572-576, 2012. 
17 Winiker M, Mantziari S, Figueiredo SG, Demartines N, Allemann P and Schafer M: Accuracy of preoperative staging for a priori resectable esophageal cancer. Dis Esophagus 31: 16, 2018

18 Chaffer CL and Weinberg RA: A perspective on cancer cell metastasis. Science 331: 1559-1564, 2011.

19 Klein CA: Parallel progression of primary tumours and metastases. Nat Rev Cancer 9: 302-312, 2009.

20 Pantel K and Speicher MR: The biology of circulating tumor cells. Oncogene 35: 1216-1224, 2016.

21 Lohr JG, Adalsteinsson VA, Cibulskis K, Choudhury AD, Rosenberg M, Cruz-Gordillo P, Francis JM, Zhang CZ, Shalek AK, Satija R, Trombetta JJ, Lu D, Tallapragada N, Tahirova N, Kim S, Blumenstiel B, Sougnez C, Lowe A, Wong B, Auclair D, Van Allen EM, Nakabayashi M, Lis RT, Lee GS, Li T, Chabot MS, Ly A, Taplin ME, Clancy TE, Loda M, Regev A, Meyerson M, Hahn WC, Kantoff PW, Golub TR, Getz G, Boehm JS and Love JC: Whole-exome sequencing of circulating tumor cells provides a window into metastatic prostate cancer. Nat Biotechnol 32: 479-484, 2014.

22 Iwatsuki M, Toyoshima K, Watanabe M, Hayashi N, Ishimoto T, Eto K, Iwagami S, Baba Y, Yoshida N, Hayashi A, Ohta Y and Baba H: Frequency of HER2 expression of circulating tumour cells in patients with metastatic or recurrent gastrointestinal cancer. Br J Cancer 109: 2829-2832, 2013.

23 Klapper LN, Glathe S, Vaisman N, Hynes NE, Andrews GC, Sela M and Yarden Y: The ErbB-2/HER2 oncoprotein of human carcinomas may function solely as a shared coreceptor for multiple stroma-derived growth factors. Proc Natl Acad Sci USA 96: 4995-5000, 1999

24 Ross JS and Mulcahy M: HER2 testing in gastric/gastroesophageal junction adenocarcinomas: unique features of a familiar test. Gastrointest Cancer Res 4: 62-66, 2011.

25 Amir E, Miller N, Geddie W, Freedman O, Kassam F, Simmons C, Oldfield M, Dranitsaris G, Tomlinson G, Laupacis A, Tannock IF and Clemons M: Prospective study evaluating the impact of tissue confirmation of metastatic disease in patients with breast cancer. J Clin Oncol 30: 587-592, 2012.
26 Khan AN, Yang W, Seifalian AM and Winslet MC: HER2 (ErbB2) receptors, a potential therapeutic target in squamous cell carcinoma of oesophagus. Br J Cancer 94: 1213-1214, 2006.

27 Amir E, Clemons M, Purdie CA, Miller N, Quinlan P, Geddie W, Coleman RE, Freedman OC, Jordan LB and Thompson AM: Tissue confirmation of disease recurrence in breast cancer patients: pooled analysis of multi-centre, multi-disciplinary prospective studies. Cancer Treat Rev 38: 708-714, 2012.

28 Hong B and $\mathrm{Zu} \mathrm{Y}$ : Detecting circulating tumor cells: current challenges and new trends. Theranostics 3: 377-394, 2013.

29 Lustberg MB, Balasubramanian P, Miller B, Garcia-Villa A, Deighan C, Wu Y, Carothers S, Berger M, Ramaswamy B, Macrae ER, Wesolowski R, Layman RM, Mrozek E, Pan X, Summers TA, Shapiro CL and Chalmers JJ: Heterogeneous atypical cell populations are present in blood of metastatic breast cancer patients. Breast Cancer Res 16: R23, 2014.

30 Reichelt U, Duesedau P, Tsourlakis M, Quaas A, Link BC, Schurr PG, Kaifi JT, Gros SJ, Yekebas EF, Marx A, Simon R, Izbicki JR and Sauter G: Frequent homogeneous HER-2 amplification in primary and metastatic adenocarcinoma of the esophagus. Mod Pathol 20: 120-129, 2007.

31 Konig AM, Reeh M, Dancau AM, Rathjens M, Gros S, Uzunoglu FG, Bockhorn M, Simon R, Sauter G, Marx A and Izbicki JR: Concordance of HER2 status in primary tumour and lymph node metastases in patients with esophageal carcinoma. Anticancer Res 33: 4975-4982, 2013.
Received August 31, 2018

Revised September 16, 2018 Accepted September 18, 2018 